\title{
Adolescent Nutrition Action as a Part of Achieving Healthy Generation in SMPN 37 Babakan Sari Kiaracondong Bandung
}

\author{
Citra Windani Mambang Sari, Iwan Shalahuddin ${ }^{\text {a), }}$, and Iqbal Pramukti \\ Faculty of Nursing, Padjadjaran University, Bandung, Jawa Barat, Indonesia \\ a)Corresponding Author: shalahuddin@unpad.ac.id
}

\begin{abstract}
Health promotion in schools is a strategic step in improving public health. This is because health promotion through the school community is quite effective in increasing public awareness in carrying out clean and healthy living behaviors. School age is very good for providing education and understanding about Clean and Healthy Life Behavior (PHBS), one of which is education about nutrition. Optimal nutrition intake, both in terms of quantity and quality, is very important for optimal growth and development. For this reason, our diet needs to be improved towards the consumption of balanced nutrition. Balanced nutrition is a balanced diet of daily food that contains nutrients in the type and amount according to the body's needs. The purpose of the activity is to create students, teachers and the school environment community to implement PHBS, create a healthy, clean and comfortable school environment, be able to improve education in schools, create health services in schools that can be put to good use, especially nutrition action. The method used is the lecture method via whatsapp, poster installation, question and answer and group discussion. The results of the health education activities were approximately 67 participants. The counseling participants looked enthusiastic when the material was given. Participants participated in the counseling happily because the counseling was carried out in a fun way. The counseling activity was conducive because the participants paid attention to the material presented well. This is evidenced by the number of participants who are interested in answering questions during the question and answer session. Participants participated in the counseling happily because the counseling was carried out using a fun online method. Counseling activities are conducive because the community pays attention to the material presented well
\end{abstract}

Keywords: Education, healthy teens, nutrition action, online

\section{INTRODUCTION}

School health unit (abbreviated as UKS) is a government program to improve health services and education, and foster a healthy school environment or the quality of school health (Ervina, Tahli, \& Mulyadi, 2019). The three main UKS programs implemented are health education, health Services and healthy school environment development. These programs need to be encouraged and socialized; therefore, all parties involved understand and support these programs (Candrawati, Widiani, Tribhuwana, \& Malang, 2015). The UKS program is expected to increase the harmonious and optimal growth and development of children in creating excellent quality of human resources (Ervina et al., 2019).

According to the Ministry of Education and Culture of the Republic of Indonesia (2019), the success key of school health unit development lies from the clean and healthy living behavior and an increase in health status for students and the school community. Improving clean and healthy living behaviour can be administered through several programs such as curricular and extracurricular activities, and other efforts outside the school. The UKS training and development activities that can be carried out during the COVID-19 pandemic are by providing information, understanding and analysis related to urgency of school health unit, school management during the Covid 19 pandemic and the urgency of Family Medicinal Plants (Khuluqo, 2021).

Teachers have an important role in the implementation of activities at UKS. The actions taken by teachers in optimizing the school health unit or UKS greatly affect the health of the school environment. The roles played by the teachers are very influential to maintain and provide facilities in preventing this COVID-19. During a pandemic, one of the teacher's roles in 
optimizing school health services can be accomplished by coordinating with local health services to spray disinfectants and provide hand washing facilities (Wulandari, 2020). In supporting the improvement of the health of the school community, teachers, especially physical education teachers, are also more involved in health education. PE teachers can use the media in providing material related to health education, and participate in more training or seminars related to health education or UKS implementation, healthy lifestyles, and other seminars related to health education. (Praditya \& N, 2017).

SMPN 37 Bandung has school health unit that can be developed. The efforts to improve school health unit are by cultivating clean and healthy school environment and getting school community used to clean and healthy behaviour. Therefore, as an effort to increase school health status, we are from nursing faculty of Padjadjaran University initiate a program to guide the health school unit of SMPN 37 Bandung particularly during Covid19 pandemic. The topic taken is Adolescent Nutrition Action to achieve Healthy Generation.

Optimal nutrition intake, both in terms of quantity and quality, is very important for optimal growth and development. For this reason, our diet needs to be improved towards the consumption of balanced nutrition. Balanced nutrition is a diet that contains nutrients in the type and amount according to the body's needs.

The principles of balanced nutrition include:

1. Consuming a variety of foods

Consuming a variety of foods is very important because there is no single type of food that contains all the types of nutrients that the body needs to stay healthy, except for breast milk (ASI). Breast milk contains all the nutrients the body needs, but it is only for newborns up to 6 months of age. In addition, there are some interrelated interaction among nutrients in our body. For example, certain nutrients require other nutrients to be circulated or digested such as digestion of carbohydrates, fats, and proteins that requires B vitamins which can be found in green leafy vegetables.

2. Getting used to clean behaviour

Clean living reduces the risk of contracting infectious diseases, which can later affect our nutritional status. While we are sick, the nutrients in the body are used mainly to fight the disease. Consequently, the growth and development of our body is not optimal. Several clean living habits include washing hands, keeping nails short and clean, wearing footwear, and covering food properly.

3. Doing physical activities

Physical activity is very important to maintain fitness and improve heart, lung and muscle function, and reduce the risk of obesity. Physical activity does not always have to be in the form of sports, all kinds of activities such as playing are also included in doing physical activity

\section{Controlling weight regularly}

One of the signs of the balanced nutrition in the body is normal weight that suits with height known as Body Mass Index (BMI). For school-age children and adolescents, the determination of nutritional status based on BMI must be adjusted according to age. By routinely monitoring our weight (and height), we can find out our nutritional status, and prevent or take action if our weight exceed the normal level.

Based on the results of the recapitulation of learning needs assessment, the participants can be grouped into several needs: 1.) Perceived needs. Some participants know the impact of managing nutritional actions such as what are not good for participants, 2.) Unperceived needs. Some participants do not know how to prevent the risk of managing nutritious actions that are harmful to health, 3.) Misperceived needs. Some participants know the dangers of not managing good and correct nutrition actions that are harmful to health, but there are still habits that are not in accordance with good and correct nutrition action management efforts. Data Recapitulation of Learning Needs Assessment Results Audience is obtained from 67 people. The respondents consist of 37 students of SMPN class $9 \mathrm{~A}-9 \mathrm{~J}$. 


\section{METHOD}

The number of participants was 67 people. The method suitable for this large group was providing education and health promotion in the form of education. The subjects in this service were students, teachers and parents. The preparatory stage started at coordinating with SMPN 37 Bandung for permit application, identification of general conditions, knowledge, behaviour and efforts to implement the adolescent nutrition action and prepare the required resources involving students of the Faculty of Nursing who are carrying out Community nursing professional activities at the school.

The method used in health education was an explanation or lecture given by the teacher to students and teachers virtually, and followed by a question and answer session. The presenters should make sure that all participants understood the material given. In the pre-test, the respondents were given oral questions about nutrition and the health counselling about the importance of managing good and correct adolescent nutrition actions to avoid health problems and safety problems. The information media for participants was compiled by a community service team who collaborated with students and conducted a Post Test through oral questions.

The counselling method used was lecturing. This method enabled the respondents easier to understand the delivered. The media used in lecturing was power point. According to Abdul Majid, 2009:138, lecturing method aims to create reasoning for participants through lecturing. Participant takes notes the materials so that participants can learn through written material from lectures. Lecturing also allows the presenter to provide outlines of lesson content and problems contained. It also stimulates participants to learn independently and foster curiosity through enriching learning, introducing new things and providing clear explanations. This method is the first step for other methods in an effort to explain the procedures that must be followed by participants.

Other method used was discussion. The participants were expected to solve the problems or answer the questions given by other participants. This method also aims at exchanging ideas, information or experiences among participants; therefore, the agreement can be achieved. These agreements are then said as the result of discussion.

\section{RESULTS}

According to the assessment of school health unit held in SMPN 37 Bandung from 26 to 28 January 2021, it was obtained the result of questionnaire distributed through google form. The google form link was given through whatsapp group of teachers and students of SMPN 37 Bandung. The total respondents were 183. The teachers were 4 people, students' parents were 10 people, and the majority respondents consisted 169 students. The respondents answered the questionnaire about their knowledge, attitude, and behaviour about Covid19 and their behaviour towards nutrition action.

Based on the result of interview to the school officers, it was obtained that there were 973 students in SMPN 37 Bandung. The total of female students were higher than that of male students. The age range of students were 11-15 years. 2 students had delay development due to they were students with special education. The dominant tribes were Sundanese and Java. The common health problems found among students before the pandemic were headaches, fever, and coughing flu. During the pandemic, there were students who were exposed to Covid19 , resulting in the cancellation of home visits. The work arrangement system for school staff during the pandemic was that there was no duty schedule so that school staff were not required to come to school.

The purpose of this health education was that after the completion of nursing actions, the students of SMPN 37 were expected to be able to understand the healthy generation of nutrition in schools. The strategies used were by working with schools, teachers and people involved in the school environment to put up posters with the theme of balanced nutrition and online counselling related to balanced nutrition. 
Health education counselling were held on Wednesday, February 03, 2021, at $1 \mathrm{pm}$. This counselling were virtually carried out via Zoom. This activity began with an opening by the MC, then speech session. As an opening, the MC asked to what extent the participants knew about nutrition management, whether the participants had experienced health problems due to not managing proper nutrition, especially the risks in learning, and what impacts would arise if they did not take these preventive measures. Based on the answers of all participants, they were quite familiar with the dangers of not making efforts to manage good and correct nutrition, but participants still did not understand what impacts would arise on students who experienced the habit of not doing proper nutrition management. Then participants were given a pre-test via google form to find out the extent of their knowledge before the material was delivered by the presenters.

The activity continued with the provision of material using PPT and video performances that had been prepared, so that participants remained interested in participating in the event and did not get bored. The material presented was about nutrition management. The presentation of the material began with the main material. The presenter immediately displayed the prepared PPT. During the presentation session, the participants seemed to be focused and listening to the material given.

Before the health education was given, the students were required to fulfil the pre-test and after the health education, the post-test was also distributed to the students as learning evaluation. Several activities followed included coordinating with school officers to monitor the students' health status, control the daily activities to the students or their parents related to the health education material that had been given, requested the students or their parents to distribute e-poster to the students who did not participate in health education, and gave education posters to be displayed in school board.

After the material was completely delivered, the videos and pictures related to the management of healthy nutritious food were given. Then, question and answer session was provided to find out the different knowledge before and after the education was given. The questions were given by the presenter and the respondents were enthusiastically answered all the questions.

\section{DISCUSSION}

Before the pandemic, socialization had ever been given to the students related to the behaviour of consuming nutritious food. Students were encouraged to always have breakfast at home because the food available in the school canteen was generally junk food. During the pandemic, the school always reminded parents to carry out health protocols. Teachers also always provided positive support and motivation to students and parents because during long distance learning, parents served the biggest role.

The system of providing health services for students during the COVID-19 pandemic was carried out through virtual counselling services, for example by telephone and information dissemination from homeroom teachers or teachers to parents and students through home visits, despite not routinely done. The school also carried out health promotion activities by installing billboards and providing hand washing facilities. During the pre-pandemic, other activities carried out by the school were socializing about drugs and reproductive health. The school also collaborated with the Community Health Centre (Puskesmas), Youth Red Cross (PMR) and the HEBAT Program organized by UNPAD medicine faculty, as well as the Pandawa Program which was held from the Bandung district which activities conducted aimed at exploring the understanding of school community regarding health protocols, symptoms and handling of Covid-19, and health mentally. Teachers in schools also had screening skills that had previously been provided through mental health screening training from the Puskesmas, and PMR. Before the pandemic, the school also held health checks related to intestinal worms, eye health, but during the pandemic the health check program was removed. However, personally, the resource person who is also the coordinator of the UKS hoped that there would be health checks such as drug screening, cigarettes, and reproductive health that can be carried out during the Covid-19 pandemic. 
The coordination between the school and the Puskesmas was fostered through the procurement of a formal cooperation program. Currently, the school is drafting a new MOU with the Puskesmas. Meanwhile, informally, the collaboration was formed through personal communication mediated by the PMR Advisory Coordinator to screen the "I'm Smart" Program. The technical implementation of the program was carried out through sending questionnaires from the Puskesmas to the school and the school asked for feedback to participate in accessing the results of the recap of the data collection that was distributed. Then, the school obtained the the data collection to support the interests of the school, such as knowing the children who consume drugs or students with mental health problems. Other Puskesmas programs that were also operationalized in schools included health checks such as measuring blood pressure, height, weight, mental health screening carried out 2 times in 1 year before the pandemic.

Tele-education to parents and students was carried out through a counseling program. Communication with parents was done first, then the problems found were followed up with family counseling. Family counseling was administered by calling the parents concerned to attend school or vice versa school officers conduct home visits to the students' homes. The policies carried out by the school to its students/staff in order to support the prevention of Covid-19 were by providing facilities that support health protocols such as disinfection tools for the school environment, socializing to students or other school residents to implement health protocols, carrying out work from home for teaching staff, scheduling picket hours for teachers, and implementing regulations for those aged 50 and over not to come to school.

According to the Public Relations of SMPN 37 Bandung, it is known that the school has a canteen, but only a public canteen used by students. At school before the pandemic, there was once a program to improve nutrition for students that encouraged students to consume nutritious foods such as 4 healthy 5 perfect principle by displaying the poster. This program was initiated by PMR members of SMPN 37 Bandung. However, this activity was considered not optimal because the school did not support fully the program. During the school pandemic, there is still a program to disseminate information and encourage students to eat nutritious food (4 healthy 5 perfect). According to Public Relations of SMPN 37 Bandung, the average type of food in the school canteen is non-nutritive food, such as $95 \%$ of the junk food. Before the pandemic, the school had not recommended for every student to have breakfast first from home, but in every homeroom teacher, it was always advised to the students to have breakfast first from home before leaving for school.

The Health Belief Model is the most commonly used theory in health education and health promotion. The concept underlying the HBM is that health behaviour is determined by personal beliefs or perceptions about disease and the strategies available to reduce disease occurrence. Personal perception is influenced by various factors that influence intrapersonal health behaviour. Judging from the process of behavior change in the Health Belief Model, behaviour will change, one of which is if individuals are given an understanding of the benefits. First look for the cause of an unfavourable behaviour, then provide counselling and detailed information about the benefits of improving his behaviour (Riauwi, H. M, 2014). This effort is carried out in health education at SMPN 37 Babakan Sari Kiaracondong Bandung.

In the trans-theoretical model, behaviour change is defined as a developmental process that takes place over a certain period of time and through several stages. In this health education process, the teacher can find out what stage the participants are at. During the health education process, it was found that the majority of participants were in the contemplation stage, i.e., individuals were more concerned about the positive and negative sides of the planned behavior change, but they were still hesitant to implement it, so this could make the individual delay the change. Kurniawati, C., \& Sulistyowati, M, 2014).

The Theory of Reasoned Action can be said successful when applied to behavior that is under the control of the individual. If the behavior is not completely under the control or willingness of the individual, he may not actually show the behavior. During the health education process, teachers try to make individuals to be motivated and to be able to independently change (Mahyarni, M, 2013). 
In the process of counselling; students seemed enthusiastic when the material was given. Participants actively engaged in the counselling because the counselling was carried out using a fun online method. The counselling activity was conducive because students paid attention to the material presented. The sustainability planning programs in the future include: 1) Providing an understanding of the importance of balanced nutrition involving all those in the school environment in social media; 2) Two-way interactive activities regarding the problems faced intensively for students to build strong healthy living habits, especially the regulation of balanced nutrition; 3) Involving elements of health service personnel in handling and preventing unhealthy habits in SMPN 37; 4) Proposing SMPN 37 as a pilot project with one of its programs, namely "Healthy Youth Generation, Nutrition Action"

This program is manifested in the provision of health education through online social media as well as placing posters and banners in the school environment. This program also provides a video about balanced nutrition and distribute it to students. It is expected that students can share the video with all community members who are around the student's residence so that they can continue to regulate balanced nutrition in their respective homes. However, people's behaviour cannot change immediately.

\section{CONCLUSIONS And RECOMMENDATIONS}

The effectiveness of teaching media can be clearly seen by all participants. Due to the counselling was done virtually so that the participants do not need to come in a place. Instead, it is enough just to listen from the virtual in their homes or workplace. This can make the material explanation more effective. The good response of the participants was seen enthusiastically to follow it from the beginning to the end of the activity. Participants actively and happily engaged in the counselling happily because the counselling was carried out in a fun way. The counselling activity was conducive because the participants paid attention to the material presented well. This could be seen from the number of participants who are interested in answering questions during the question and answer session.

Based on the result of counselling online, it is expected that students and their parents, as well as the school can make preventive and health education promotion efforts to prevent health and safety problems due to improper nutrition management.

\section{REFERENCES}

Anwar, R. S., Rasyid, W., \& Mariati, S. (2019). Pelaksanaan Usaha Kesehatan Sekolah (UKS) di SMP Negeri 3 Pelepat Ilir Kabupaten Bungo Jambi. 2(4), 1-5.

Apriani, L, \& Gazali, N. (2018). Pelaksanaan trias usaha kesehatan sekolah (UKS) di sekolah dasar. Jurnal Keolahragaan, 6(1), 20-28.

Apriani, Leni, \& Gazali, N. (2018). Pelaksanaan trias usaha kesehatan sekolah (UKS) di sekolah dasar. Jurnal Keolahragaan, 6(1), 20-28. https://doi.org/10.21831/jk.v6i1.14456

Azwar, A. (2012). Pengantar Ilmu Kesehatan Lingkungan. Jakarta: Yayasan Mutiara.

Budiono, M. A., \& Sulistyowati, M. (2014). Peran Uks (Usaha Kesehatan Sekolah) Dalam Penyampaian Informasi Kesehatan Reproduksi Terhadap Siswa Smp Negeri X Di Surabaya. Jurnal Promkes, 2(1), 58-65.

Candrawati, E., Widiani, E., Tribhuwana, U., \& Malang, T. (2015). Pelaksanaan Program Uks Dengan Perilaku Hidup Bersih Dan Sehat (Phbs) Siswa Sekolah Dasar Di Kecamatan Kedung Kandang Kota Malang. Care, 3(1), 15-23.

CDC. (2020). A Quick Guide for Teachers How Do I Set Up My Classroom?

Ervina, Tahli, T., \& Mulyadi. (2019). Pelaksanaan Program Usaha Kesehatan Sekolah (UKS) Di Puskesmas. Jurnal IImu Keperawatan, 6(2), 11-21.

Fridayanti, D. V., \& Prameswari, G. N. (2016). Peran UKS (usaha kesehatan sekolah) dalam upaya penanggulangan obesitas pada anak usia sekolah. JHE (Journal of Health Education), $1(2$. 
Harmawan, D. F. (2015). Skripsi - Tingkat Keterlaksanaan Usaha Kesehatan Sekolah (UKS) pada Sekolah Dasar Negeri Se Kecamatan Kokap Kabupaten Kulonprogo Tahun Ajaran 2014/2015. Yogyakarta-UNY.

Kemendikbud. (2020). Buku Saku Pedoman Edukasi Perubahan Perilaku. Kemendikbud RI. (2019). Buku Pedoman Pembinaan dan Pengembangan UKS. Kementerian Pendidikan Dan Kebudayaan Republik Indonesia.

Kemenkes. (2019). Buku Pedoman Pembinaan dan Pengembangan UKS. Kementerian Pendidikan Dan Kebudayaan Republik Indonesia.

Kemenkes RI. (2020). Kolaborasi Sektor Pendidikan dan Kesehatan.

Kementerian Pendidikan dan Kebudayaan. (2014). Pedoman Pelaksanaan UKS di Sekolah. Kementerian Pendidikan Dan Kebudayaan Direktorat Jenderal Pendidikan Dasar.

Kementrian Kesehatan. (2016). Promosi Kesehatan. Direktorat Promosi Kesehatan \& Pemberdayaan Masyarakat.

Khuluqo, I. El. (2021). Kunci Sukses Pembinaan Usaha Kesehatan Sekolah (Uks )Pada Masa Pandemi Covid-19 Sebagai Penguatan Manajemen Sekolah.2(1), 125-130. https://doi.org/10.31949/jb.v2i1.651

Nies, M. A., \& McEwen, M. (2015). Community/Public Health Nursing (6th ed.). St Louis, Missouri: Elsevier.

Pemerintah Kabupaten Buleleng. (2019, September). Pembinaan Sekolah Sehat. Praditya, D. K., \& N, J. Do. H. (2017). Survei Pelaksanaan Usaha Keseharan

Sekolah (UKS) dan Peran Guru PJOK dalam Pendidikan Kesehatan di SMP Negeri Se Kecamtan Gempol Kabupaten Pasuruan. Jurnal Pendidikan Olahraga Dan Kesehatan, 05(2), 224-231.

Prasetyo, Y. B. (2014). Pelaksanaan Program Usaha Kesehatan Sekolah Dalam Upaya Meningkatkan Derajat Kesehatan Pada Anak Usia Sekolah Dasar di Lombok Timur. Jurnal Kedokteran YARSI, 22(2), 102-113. https://doi.org/10.33476/JKY.V22I2.306

Prasetyo, Y. B., Hudha, A. M., \& Kunci, K. (2014). Pelaksanaan Program Usaha Kesehatan Sekolah Dalam Upaya Meningkatkan Derajat Kesehatan Pada Anak Usia Sekolah Dasar di Lombok Timur Implementation Health School Program to Improve Health Status for School Age at East Lombok. 22(2), 102-113.

Rosita, R. (2011). Profil Kesehatan Indonesia. Jakarta. Kementrian Kesehatan RI.

Setiawan, M., \& Hidayat, F. R. (2018). Gambaran Sikap Guru Terhadap FungsiUKS di SD Muhammdiyah 4 Samarinda.

UNICEF, \& SPEAK. (2018). Strategi Komunikasi Usaha Kesehatan Sekolah Madrasah (UKS/M). 1-37.

WHO. (2020). Key Messages and Actions for Prevention and Control in Schools. 1-13.

Wulandari, I. M. (2020). Peran Guru Mengoptimalkan Unit Kesehatan Sekolah Untuk Melakukan Pencegahan Covid-19. Edukatif: Jurnal IImu Pendidikan, 2(1), 71-77. https://doi.org/10.31004/edukatif.v2i1.88 


\section{APPENDIX}

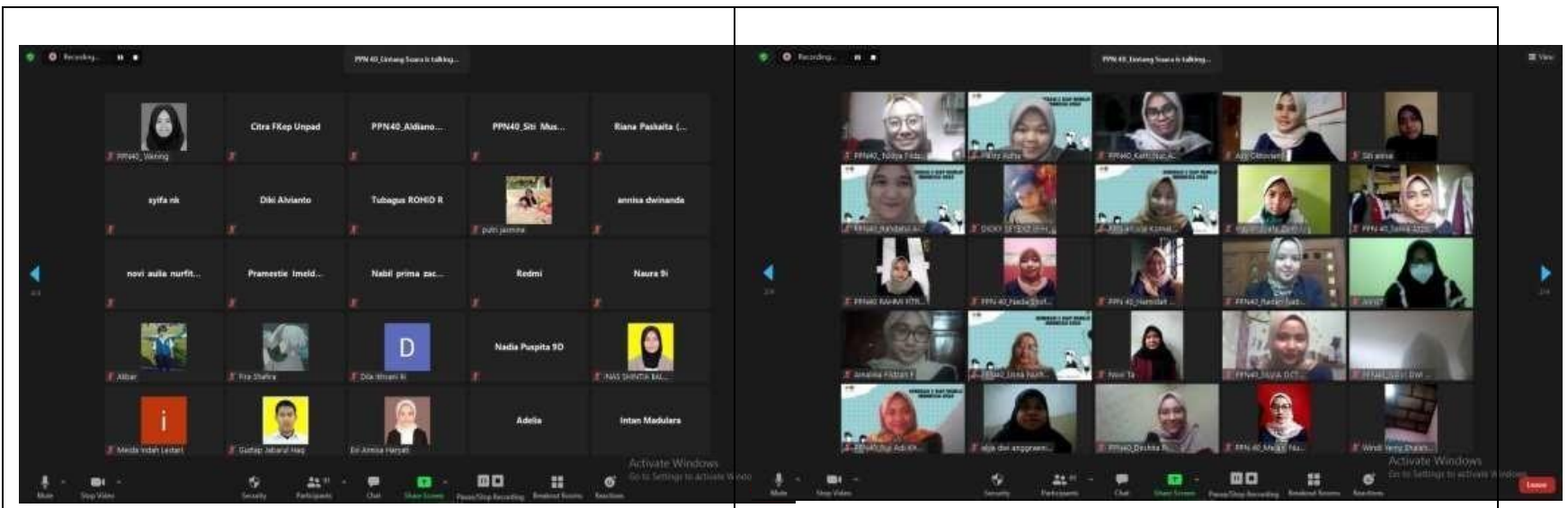

Figure 1. Online documentation of health Figure 2. Online documentation of health education activities 1 education activities 2 